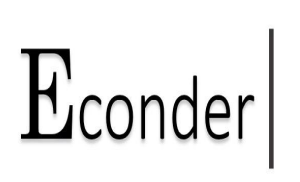

ECONDER

International Academic Journal

Cilt / Vol: 2, Say1/Issue: 1, 2018

Sayfa: $82-89$

Received/Geliş: Accepted/Kabul:

[20.-04.-.2018] - [25.-04-.2018]

Tek Bina ve Kampüs Hastanelerinin Karşılaştırılması

Şakir Sarp Pınar

Ankara Üniversitesi, Tıp Fakültesi, SBE Doktora Öğrencisi

0000-0002-6016-5451

Öz

sakirpinar@gmail.com

$\mathrm{Bu}$ araştırmanın amacı aynı üniversitenin tek bir yapısını ve kampüs yerleşkelerini karşılaştırmak, bu vesile ile hastaların tercihlerini ve memnuniyetlerini etkileyen faktörleri belirlemektir. Aynı üniversitenin iki yerleşkesinden 100 hasta seçilmiştir. Birinci hastane şehir merkezinde yer alan ve tek bir binadan oluşan bir yapıyken diğer hastane farklı sağlık tesisleri, geniş alanları, bahçeleri ve yürüyüş yerleri olan bir kampüs hastanesidir. Anket, yerleşime göre gruplandırma yapılmadan analiz edilmiştir çünkü birçok hasta iki yerleşkeyi de kullanmıştır. Hastaların tamamı (\%100) hastanelerde her zaman problem yaşayacaklarını söylemişlerdir. Hastaların \%36's1 kampüs hastanesine gitmeyi tercih ederken \%24'ü tek bina hastaneyi tercih etmişlerdir. Hastaların \%40'1 evlerine yakın olan hastaneye gideceklerini söylemişlerdir. Kampüs hastanesini tercih eden katılımcılar, arabalarının olmasını (\%32), bahçelerin güzel olmasını ve sigara içilebilecek alanların olmasını sebep olarak göstermişlerdir. Tek bina hastaneyi tercih eden katılımclar hastanelerin evlerine yakın olmasını (\%60) ve hastaneyi iyi bilmelerini sebep olarak göstermişlerdir.

Anahtar Kelimeler: Çevre Dostu Hastane, Kampus Hastanesi, Tek Bina Hastane, Hasta Memnuniyeti

\title{
Comparing Single-Building and In-Campus Hospitals
}

\begin{abstract}
The aim of this study is comparing single building, and in-campus settlements of the same university hospital to determine the factors that affect patient preference and satisfaction. A total of 100 patients were randomly selected from the two settlements of the same university hospital. The first hospital is a single building hospital placed in a
\end{abstract}


central location in the city, and the other is a campus hospital that formed of different healthcare facilities, which has wide free spaces, gardens, and walkways. The questionnaires were analyzed together without grouping according to the settlement, because many patients used both of the settlements. All of the patients $(100 \%)$ declared that they always that they will have a problem at hospitals. $36 \%$ percent said that they prefer to go to campus, $24 \%$ said that they prefer single building hospital, and $40 \%$ said that they go to one that is closer to them.

Keywords: Environment Friendly Hospital, Campus Hospital, Single Building, Patient Satisfaction

\section{Introduction}

Urban landscape architecture is one of the major components of quality of life of the citizens, and this is also an ongoing process that requires continuous rearrangement of living quarters according to emerging needs of civil life. The concept and planning of facilities are increasingly considered in a human-centered comprehension. As might be expected, hospital designs and their interaction with surroundings and environment are not out of this concept. The new hospital constructions are planned according to a patient-centered design. The components of this design include many features to ensure highest level of patient satisfaction. Some of these features are using sound absorbing materials to reduce noise in patient rooms and building, increasing natural light in closed spaces to decrease patient anxiety, and reducing multioccupancy patient rooms to single-patient rooms. Another important component of this patient-centered design is giving places to natural elements like gardens, green spaces, ponds, etc.(Marcus, 2017, p. 1 ; Sherman, 2005, p. 167-183) But unfortunately, there are still many westernized hospitals without any interaction with environment, and stand as high buildings without or minimal patient-centered satisfactory peripherals.(Horsburg, 1995, p. 735-740 ; Ulrich, 1992, p. 97104)

The facts above point out that the architectural design of the healthcare facilities are important to provide patient satisfaction, and also important to increase quality of healthcare services. There are many 
previous reports about that well-designed environment friendly hospitals increase patients' wellbeing. .( Beaucheminand Hays, 1996, p. 49-51; Warny, 2004, p. 10-20) But in contrary, there are recent studies that argues the design of the hospital buildings are only minimally contributed to patient satisfaction, and main component is still the quality of clinical care in healthcare facilities. (Siddiqui, 2015, p.165-171)

From the aspects of these literature data, we aimed to compare single building hospitals with in-campus hospitals, which the latter is more environment friendly, regarding patients' attitudes, beliefs, and satisfaction.

\section{Material And Method}

This study was conducted in two different hospitals of the same university. A total of 100 participants were randomly selected from the patients at these hospitals, and 50 participants were asked to complete a study questionnaire including 17 questions that evaluates the hospital conditions and patient's attitude when getting healthcare service at each facility. Since majority of the patients took service from both of the hospitals, all questionnaires evaluated without categorizing according to the settlement.

Each hospital is a large-scale tertiary healthcare facility with 1200 inpatient beds. The single building hospital has limited availability of gardens, free-spaces, and social activity areas. The building is located in a crowded geographical region with high traffic density, which also causes high ambient noise. The only advantage of this hospital is its geographical location, which is one of the central regions of the city.

The other in-campus hospital is located in a historic cavalry barracks. The historic buildings were transformed to hospital facilities, and some new buildings were also constructed in the free zones. Campus has wide areas of ride ways, free spaces, and green zones, but still need some landscape renovation. The campus has very low density of traffic, and less crowded due to its wide settlement. This also reduces the ambient noise around patient wards. 
These two facilities are operating in conjunction with each other. Some of the departments are only located in one of them, and some other are placed in each of the facilities. The institutional vehicles provide patient transportation between settlements. These two healthcare centers are administered from a common dean's office of the university.

\section{Results}

From the 100 participants of this study, 52 were females (52\%) and 48 were males (48\%). All of the patients $(100 \%)$ declared that they always have a feeling about experiencing a problem related with procedures and building usage prior to applying hospitals for a health problem. And $92 \%$ of the patients declared that they face with more than one problem when they come to hospitals.

The most important problems of patients were neglect $(48 \%)$, personnel $(24 \%)$, cannot finding the place looking for $(12 \%)$, chaos $(6 \%)$, and queues (5\%). When they asked for what they do when they experience a problem, $40 \%$ declared that they report the situation, $20 \%$ said they shout and dispute, $20 \%$ said they do nothing because they are used to these problems, $10 \%$ said they try to damage toilettes by throwing obstructive materials, $6 \%$ said they fight, and $4 \%$ said they try to damage wares like breaking glasses.

The questions related with information and reception services revealed that $97 \%$ of patients had problems with these services, $78 \%$ needed information more than one time, $100 \%$ requested that information desk should be at entrance of the hospital, and $64 \%$ did not feel themselves comfortable when applying for information. From the ones that felt themselves comfortable when applying to information desk, $88 \%$ felt discomfort not during the first time, but in the latter applications.

The questions related with toilettes showed that only $48 \%$ of participants said that their locations are appropriate, but only $12 \%$ declared they are functionally appropriate to use. Thirty-six percent of participants had to ask where the toilettes were, and 16\% said they had to pass from a barrier or ask someone to use the toilettes. $62 \%$ of them said they feel discomfort when asking for the toilettes. $56 \%$ of the participants prefer to ask for "toilette", and $44 \%$ preferred to ask for 
"lavatory". Majority of the patients (94\%) were uncomfortable with touching somewhere in the hospitals, for example when sitting or standing.

The patients also asked for the gardens at the hospital. Forty-four percent declared that hospital garden meant fresh air and breath for them, 29\% said garden meant smoking, 12\% answered peace and comfort, and $10 \%$ said silence. And, when the participants asked what a hospital smell meant for them, 52\% said anxiety, 36\% said fear, and 10\% said nausea.

The participants also asked for their preference for the two settlements of same university hospital. Thirty-six percent said that they prefer to go to campus, $24 \%$ said that they prefer single building hospital, and $40 \%$ said that they go to one that is closer to them. When the factors affect this preference was asked, participants that said they would prefer campus declared that because they have a car (32\%), gardens are good $(26 \%)$, and they are able to smoke $(24 \%)$. The participants who prefer single building hospital said that hospital is close to them $(60 \%)$, and they knew that hospital well (24\%).

\section{Discussion}

This study evaluated the patient preference in admissions to two different settlements of the same tertiary university hospital. One of the settlements included a single building hospital, and the other was an incampus health facility settlement. The anticipated reasons for preferring single building hospital was its central location, and for in-campus hospital it was the peripherals and environment friendly structure. According to the results, patient preference is driven by the ease of accessibility and being accustomed to the hospital.

A previous systematic review about the effects of environment on human wellbeing reported that natural landscapes and wildlife in urban areas have substantial positive effects on emotional, cognitive, developmental, behavioral, and social wellbeing of people living in these areas. (Rohde and Kendle, 1994) Healthcare facilities are also an 
important compound of urban life and their interactions with environment are a major component of patient well-being in many dimensions. For example, accessibility to healthcare facility, ergonomic measures for disabled or elderly people, traffic density, ambient noise, and etc. are all critical items for people to feel themselves comfortable, to decrease their anxiety, and to cope with their treatment process. There are many studies that reported visual environmental quality and physical health. In one of these studies, Ulrich(Ulrich, 1984, p. 420-421) evaluated surgical patients according to their view as the ones with a window looking to a natural scene, and the ones looking to a brick wall.The patients with open views had had shorter postoperative hospital stays, received fewer negative evaluative comments in nurses' notes, and took fewer potent analgesics than 23 matched patients in similar rooms with windows facing a brick building wall. These favorable outcomes were also reported in various studies. Verderber reported that patients with severe injuries from accidents or diseases prefer natural scenes,( Heerwagen,1990, p. 269-280) and Heerwagen reported that a large painting of a natural scene decreases the anxiety level of patients waiting at the dentist clinic.

As the literature data suggests, hospitals should be considered as living organisms with their designs, gardens, locations, transportation, personnel, and equipment. But, of course, these are not the only factors that affect quality of services in a healthcare facility. A recent study by Siddiqui et al. showed that a new building is not the main factor for patient satisfaction, and only had an impact on 1 of 4 patient satisfaction measures, and clinical care is likely to be the most important determinant of patient satisfaction. ${ }^{1}$

\section{Conclusion}

Being incorporated into nature and environment is important for patients to feel themselves comfortable and to increase their satisfaction from the healthcare services. The comparison of two settlements of the same university hospital with different environmental peripherals in this study showed that environment friendliness is an important factor for the people seeking healthcare service, but accessibility and habits

'Siddiqui Z.D., p.165-171.

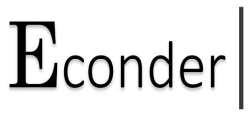

ECONDER

International Academic Journal

[Issn:2602-3806 ]
Cilt / Vol : 2,

Say1/Issue: 1 ,

2018 
are also important factors in their preferences. Renovations in hospitals should be planned to maximize patient satisfaction, accessibility, and usage patterns.

\section{REFERENCES}

Beauchemin K.M. and P. Hays, (1996). Sunny Hospital Rooms Expedite Recovery From Severe and Refractory Depressions, J. Affect Disord, 40, $1-2$, p. 49-51.

Heerwagen J.H., (1990). Psychological Aspect of Windows and Windoe Design in Proceedings of the 21st Annual Conference of the Enviromental Design Research Association, R.I. Selby et. al. (ed), EDRA, Oklahama City, p.269-280.

Horsburg C.R. Jr., (1995). Healing by Design, N. Engel J Med., 333, 11, p. 735-740.

Marcus C.C., (2007). Healing Gardens in Hospital, Interdisciplinary Design and Research, e-Journal, 1(1).

Sherman S.A., et. al., (2005). Post-occupancy Evoleation of Healing Gardens in a Pediatric Cancer Center, Landscape and Urban Planning, 73, 2-3, p. 167-183.

Siddiqui Z.D., et. al., (2015). Changes in the Patient Satisfaction Relead to Hospital Renovation: Experience with a New Clinical Building, Journal of Hospital Medicine, 10, 3, p. 165-171.

Rohde C.L.E. and A.D. Kendle, (1994). Human Well-being Natural Lanscapes and Wild Life in Urban Areas in English Nature, English Nature Science Publication, Peterborough.

Ulrich R.S., (1992). Effecth of İnterior Design on Welness: Theory and Recent Scientific Research, Journal of Healthcare Design, 3, 97-109. 
Ulrich R.S., (1984). View Through a Window May Infuluence Recovery from Surgery, 224,4647, Science, p. 420-421.

Verderber S., (1986). Dimension of Person Windoe Transaction in the Hospital Enviroment, Enviroment and Behavior, 18, p. 450-466.

Warny J.V., et. al., (2004). Evaluation of the Built Enviroment at a Cildren Covelescent Hospital: Development of the Pediatrich Quality of Life Inventory Parent and Staf Satisfaction Meassures for Pediatrich Health Care Facilities, Journal of Developmental \& Behavioral Pediatrics, 25, 1, p. 10-20. 